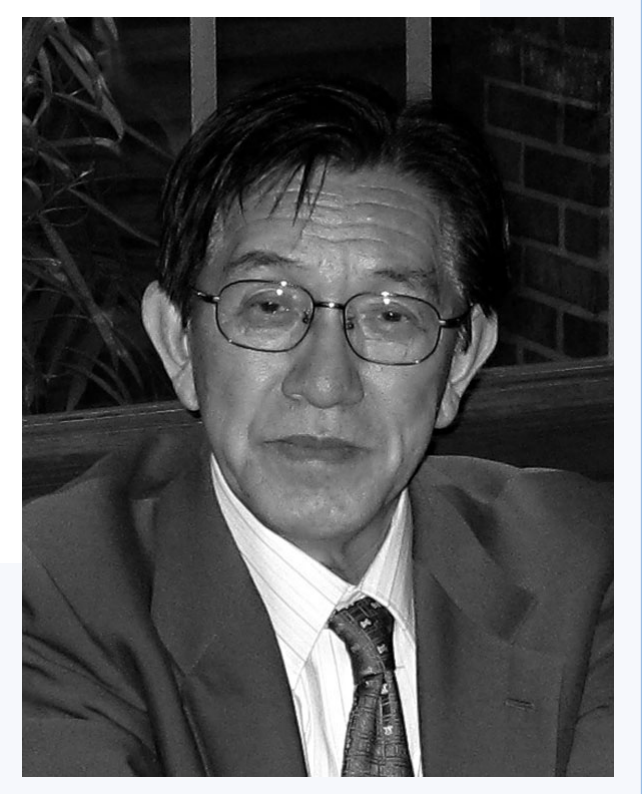

\title{
IEEEマイルストン 日本ツア一を迎えて
}

\section{松 本 栄 寿}

IEEE JCHC幹事

このたび，日本の技術遺産をアメリカ人に披露する旅， IEEE Technical Tour of Japanを迎えた. ツアーは, 2012 年5月 20 日〜 28日の日程で京都から名古屋, 東京へと 10 の マイルストンを巡った. 一部の博物館展示を含め, 実物と 発明の場所である。

アメリカに本部をおく学会IEEEでは，1980年に歴史セ ンターを設立し，まず自己の歴史の散逸を防いだ。1983年 には「マイルストン」として，社会に貢献した技術を表彰 する制度を発足させた，技術の歴史の理解を進めて，技術 者の地位向上を計るのが目標である.さらに技術をより周 知させようと，IEEEのテクニカルッアーを始めた。

第1回パナマッアー (2010年3月) は運河の旅である。ス エズ運河の技術を持ち込んだフランスの土木工事は失敗, 熱帯病対策から着手したアメリカが勝った. 運河はすべて を電気動力・電気通信に切替えたGE社が成功した. 運河 が開通した1914年の技術が現役で稼働している姿に接する と, 今でも新鮮な感銘を覚える (32名参加).

第2回UKッアー (2011年5月) は産業革命の地, イギリ ス・スコットランドである. 電気の理論, 発明, 技術の原 点は20世紀の初めまでは大英帝国である. フランクリン, マクスウエル，ファラデーと電気の元祖が見られる. 世界 中に海底ケーブルを敷設し, 電信網を築き上げたのはイギ リスの技術と資本がはじめであった (50名参加).

第3回日本ッアー (2012年5月)を企画するにあたっては どんな内容にするか, 知恵を絞ったのがマイルストンを中 心に置く旅である. IEEEのマイルストンは120件をこえ， 日本も17件となった. 新幹線, デジカメは日本の技術と知
られているが，ほかの技術は欧米の模倣と見られている. 日本にも永い技術の歴史があることをマイルストンの実物 で見てもらおう. 参加者には米軍の一員として日本に駐在, 日本の復興を体験した方々もある. 電気街秋葉原, 江戸博 の文化も体験していただいた (27名参加).

これまでの17件のマイルストンから本学会に関連が深い 分野を挙げると, 八木・宇田アンテナ (1924), 富士山頂 レーダ (1964), VHS家庭用ビデオ (1976), 高柳式電子テ レビ (1924〜 1941), 太平洋横断テレビ衛星中継 (1963), 直接衛星放送サービス (1984), G3 FAX国際標準化 (1980) などと身近な技術が活躍していることに気づく.

日本は明治から技術立国・産業立国を目指し, 教育制度 や技術を学ぼうとお雇い外国人を招いた。第1次世界大戦 に参画，富国強兵，第2次世界大戦に挑んだが，総合技術 とエレクトロニクに敗退した。戦後は再び欧米からの技術 導入を急ぎ, 高度成長を自賛し, Japan as No.1の幻想に 走った。一途に技術開発を目指したが，産業遺産や技術遺 産に目を向けることは少なく，まして実地に訪れることは なかった.気がつくと技術者が知恵を絞り汗を流した多く の技術遺産は残されてない. 遺産から歴史を学べる欧米と の格差は大きい.

IEEE Technical Tour of Japanの一行は, ご夫婦で約 100万円の費用を自分で払い8日間をさいて来日している. 目的はディスカウント品の購入や観光ではなく, 技術遺産 を訪れる旅である. 改めてIEEEメンバの技術遺産への評 価と, 参加者の認識の深さを感じたツアーであった。これ からの日本人が見習いたい行動力である。 